\title{
A ÉTICA CORPORATIVA E O CENÁRIO COMPETITIVO: UMA ANÁLISE DOS DILEMAS ÉTICOS NAS RELAÇõES DE TRABALHO CONTEMPORÂNEAS A PARTIR DO FILME “O CORTE" (LE COUPERET)
}

\author{
THE CORPORATE ETHICS AND COMPETITIVENESS: AN ANALYSIS OF ETHICAL DILEMMAS IN \\ CONTEMPORARY LABOR RELATIONS FROM THE MOVIE “LE COUPERET”
}

DOI: http://dx.doi.org/10.12712/rpca.v6i3.175

\begin{abstract}
Fábio Francisco de Araujo
fabiofdearaujo@gmail.com

Departamento de Administração (IAG) - Pontifícia Universidade Católica do Rio de Janeiro - Rio de Janeiro - RJ, Brasil
\end{abstract}

\author{
Patricia Amélia Tomei \\ patomei@iag.puc-rio.br \\ Departamento de Administração (IAG) - Pontifícia Universidade Católica do Rio de Janeiro - Rio de \\ Janeiro - RJ, Brasil
}

\section{Resumo}

O fenômeno global contribuiu para a exclusão das fronteiras entre países e economias, impactando fortemente a sociedade contemporânea. Observa-se o surgimento de uma nova lógica para condução das atividades empresariais, que proporciona a formação de um ambiente altamente competitivo, onde se impõem novos modelos de relações de trabalho e dilemas éticos. Dessa forma, o presente artigo tem por objetivo analisar o discurso sobre as mudanças nas relações de trabalho presente no filme francês $O$ Corte (Le Couperet). Este estudo adotou o método de análise qualitativa de imagens em movimento, realizando-se uma descrição do filme nas sequencias (unidades narrativas) e, por fim, realizando uma análise de conteúdo. A metodologia utilizada partiu da premissa de que as produções cinematográficas são reflexos de expressões culturais e abordam questões que contribuem para a análise de fenômenos reais. Ao estreitar as relações entre cinema e sociedade, os filmes exprimem o reflexo das crenças e valores dominantes na cultura. 0 filme $O$ Corte parece sinalizar, assim, para os riscos apontados por autores como Ransome (1999) sobre o efeito corrosivo desses novos arranjos na crença do trabalho como fonte de realização das expectativas materiais e psicológicas dos indivíduos. 0 artigo aponta a discussão da ética corporativa como um instrumento útil aos membros da organização, visando reeducar os indivíduos para fazer com que os efeitos de um ambiente de alta competitividade sejam mitigados e, assim, buscar o equilíbrio entre a cooperação e a assertividade, respeitando os limites sociais e morais.

Palavras-chave: Dilemas éticos. Competitividade. Globalização. Relações de Trabalho.

\section{Abstract}

The global phenomenon contributed to the exclusion of borders between countries and economies, heavily impacting contemporary society. We observe the emergence of a new logic for the conduct of business activities, providing the formation of a highly competitive environment, which impose new models of working relationships and ethical dilemmas. Thus, this article aims to analyze the changes in labor relations and the ethical dilemmas imposed on organizations and the professionals who work in a global society. This study employed the method of qualitative analysis of moving images, performing a description of the movie sequences (narrative units) and finally conducting a content analysis.The methodology used was based on the premise that the film productions are reflections of cultural expressions and address issues that contribute to the analysis of real phenomena. To strengthen relations between cinema and society, films express the reflection of the beliefs and the core values of the culture. This assumption was used for the election of the French Film "Le Couperet" (original title) 


\section{A ética corporativa e o cenário competitivo: uma análise dos dilemas éticos nas relações de \\ trabalho contemporâneas a partir do filme "0 Corte" (Le Couperet)}

as an object of analysis, in that it provides a timely view on the world of work and its transformations in modern corporations. The film seems to signal, thus the risks pointed out by authors such as Ransome (1999) about the corrosive effect of these new arrangements work in belief as a source of realization of material and psychological expectations of individuals. The article points out the discussion of corporate ethics as a useful tool for members of the organization in order to retrain individuals to make the effects of a highly competitive environment are mitigated and thus seek a balance between cooperation and assertiveness, respecting the social and moral boundaries.

Key-words: Ethical dilemmas. Competitiveness. Globalization. Labor Relations.

\section{Introdução}

As empresas pressionadas pelas atuais e intensas mudanças no ambiente externo e competitivo começam a rever seus valores, códigos de ética e conseqüentemente mudar suas práticas administrativas (Cressey e Moore, 1983; Mathews, 1987; Metzger et al., 1993).

A globalização da economia contribuiu para a exclusão das fronteiras entre países e economias, entre sociedade e organização (Vogl, 2000; Daigneault et al., 2001; Santos, 1996). Da organização, entendida como uma constelação de interesses cooperativos e competitivos que possuem valor intrínseco (Donaldson e Preston, 1995), formada pelos stakeholders (Freeman, 1984; Carroll, 1996; Sethi, 1999), são exigidas novas posturas morais na forma de conduzir seus negócios.

Estudiosos (Arrighi, 1996; Canclini, 2003; Harvey, 1992; Kotler, 1986) ensinam que tais mudanças exigem de todos os seguimentos da sociedade, entidades públicas e privadas, empresas e cidadãos; a compreensão do fenômeno global para que todos possam participar de forma ativa, respeitando as culturas e as necessidades de cada povo.

A globalização, a alta rotatividade de novas tecnologias de informação, as automações de fábricas, o ingresso de minorias no mercado de trabalho e outros fatores (Nadler e Lawler, 1983), demandam uma postura mais imediatista para que as organizações sobrevivam nesse novo sistema. As estruturas e os processos organizacionais ideais passaram a ser aqueles que permitem uma organização flexível.

Segundo Rifkin (1995) milhões de trabalhadores já foram definitivamente eliminados do processo econômico. De outro lado, funções e categorias de trabalho inteiras já foram reduzidas, reestruturadas ou desapareceram. Trabalhadores por toda a parte se chocam com o que parece ser uma "recuperação sem empregos", enquanto que todos os dias as companhias anunciam que se tornam mais competitivas globalmente.

Neste cenário de globalização e competitividade, as empresas precisam desenvolver estratégias que ao mesmo tempo garantam o seu posicionamento nos mercados domésticos e a expansão em outros mercados (Harvey, 1992; Kotabe e Helsen, 2000; Kotler, 1986). Este posicionamento dual representa uma vantagem importante na dinâmica do mercado mundial, pois estar presente em diferentes mercados é se fazer conhecer e reconhecer em um ambiente de competitividade cada vez mais global (Kotabe e Helsen, 2000; Santos, 1996). Vários fatores influenciam o sucesso ou o fracasso das empresas no mercado global, tais como: compreensão dos movimentos da concorrência, desenvolvimento tecnológico, observância das culturas regionais, entre outros (Hamel e Prahalad, 1985; Lévy, 1997). As empresas que conseguem adaptar-se melhor e, sobretudo, mais rápido às novas exigências do mercado têm grandes chances de sucesso e abrem caminho para o crescimento além de suas fronteiras (Kotabe e 
Helsen, 2000; Hamel e Prahalad, 1985; Vakaloulis, 2001).

Em decorrência desse processo, a temática do mercado de trabalho e sua relação com as questões éticas e culturais é objeto de reflexão de inúmeros estudiosos com abordagens e encaminhamentos teóricos diversos (Arrighi, 1996; Canclini, 2003).

Muitas empresas têm recorrido a novos modelos organizacionais através de reengenharias, reestruturações produtivas, terceirização da mão de obra, downsizing, e novos arranjos nas relações de trabalho (Cappelli, 1999; Danjou, 2002; Harvey, 1992; Ransome, 1999; Sennett, 1999), com o intuito de melhorar o seu alinhamento estratégico e cultural para enfrentar esse cenário competitivo (Arrighi, 1996; Greenberg, 1999; Harvey, 1992).

Tendo em vista essas considerações, este trabalho tem por objeto analisar o discurso sobre as mudanças nas relações de trabalho, a partir do filme $O$ Corte (Le Couperet, 2005) ${ }^{1}$. Considerando as possibilidades de reflexão teórica geradas pela análise de obras de arte e a sua importância na afirmação e transformação da cultura (Suarez e Tomei, 2007), o interesse nessa produção em particular reside no fato de que essa obra permite trazer ao debate a discussão sobre o impacto dos ambientes competitivos nas relações de trabalho e os dilemas éticos que são impostos aos profissionais de hoje para lidar com os novos arranjos organizacionais.

As produções cinematográficas, como reflexos de expressões culturais, podem abordar questões que contribuam para compreensão de fenômenos reais (Hirschman e Stern, 1994). Ao longo da última década, diversas produções cinematográficas têm chamado os fenômenos que ocorrem no ambiente corporativo ao centro do debate. Não apenas os documentários (The Corporation, 2003; Super Size Me, 2003) - gênero que na sua essência procura fazer a crítica e a reflexão sobre a realidade - mas também diversas obras ficcionais lançaram seu olhar crítico para as empresas nesse início de século. Filmes como 0 Closet (Le Placard, 2001), Em boa companhia (In Good Company, 2004), $O$ Corte (Le Couperet, 2005) e $O$ que você Faria? (El Método, 2005), O Diabo Veste Prada (The Devil Wears Prada, 2006), A Caixa (The Box, 2009), Amor sem Escalas (Up in the Air, 2010) são exemplos de produções que têm em comum uma representação crítica sobre as novas relações de trabalho e inserção organizacional tema que, também no ambiente acadêmico, gera reflexões de autores como Rosseau (1995); Kanter (1997); Cappelli (1999); Sennett (1999), entre outros.

0 filme $O$ Corte (Le Couperet, 2005) foi escolhido para a análise proposta neste estudo por oferecer uma visão oportuna sobre o mundo do trabalho e suas transformações nas modernas corporações. Dessa forma, o trabalho pretende traçar uma discussão temporal sobre os dilemas éticos que permeiam as organizações e os profissionais inseridos no atual ambiente competitivo. A proposta do trabalho é promover um debate das questões suscitadas, por meio do recorte provocador proporcionado pelo filme analisado, pensar na relevância social das questões denunciadas pela obra, e chamar os estudiosos das Ciências Sociais em geral, e da gestão em particular, a lançar um olhar mais acurado sobre o tema.

Além do filme mencionado acima, será considerada também a leitura de outros agentes sociais, como pensadores sociais e produtores artísticos, que inseridos no atual ambiente competitivo, são capazes desenvolver críticas úteis para construção reflexiva e fornecer, por

\footnotetext{
1 Baseado em um romance de Donald Westlake (The Ax), o filme tem como título original "Le Couperet". 0 roteiro, elaborado por Constantin Costa-Gravas, que também dirige o filme, contou com a colaboração de JeanClaude Grumberg. José Garcia, Karin Ward e Geordy Monfils integram o elenco. A produção envolveu profissionais da França/Bélgica/Espanha e foi produzido em 2005. No Brasil, foi lançado em 2006.122 min.
} 


\section{A ética corporativa e o cenário competitivo: uma análise dos dilemas éticos nas relações de trabalho contemporâneas a partir do filme "0 Corte" (Le Couperet)}

meio de seu trabalho ou de sua crítica, informações para retratar situações e fenômenos que podem trazer significativas contribuições para o comportamento organizacional.

Na sessão a seguir, é apresentando um referencial teórico sobre a questão da globalização e da competitividade, da evolução das relações de trabalho e da ética corporativa, com os dilemas éticos que se impõem no cenário organizacional. Nesse sentido, o filme "O Corte" será apresentado como um pano de fundo para realçar as mudanças ocorridas nas relações de trabalho e favorecer uma visão crítica sobre a nova ética de trabalho e suas transformações nas modernas corporações.

\section{Referencial Teórico}

\section{As Organizações e a Competitividade do Mercado Global}

0 fenômeno global provoca sérias "interferências" no contexto social, como desregulamentação, privatização, intercâmbios culturais, desemprego etc. Com mudanças cada vez mais aceleradas, os países e as organizações são levados a repensar suas políticas e estratégias, com objetivo de alcançar uma continuada elevação nos níveis de competitividade e de excelência. 0 desemprego como realidade cotidiana que acompanha esta competitividade e esta globalização tem sido associado por muitos autores a políticas neoliberais, onde a priorização do lucro como caminho da retomada do crescimento empresarial tem sido questionada.

Um dos autores que tem contribuído ao tema é Forrester $(1997,2001)$ que a partir da vinculação da globalização, da competitividade, do ultraliberalismo e da produtividade com o mundo trabalho e o desemprego na sociedade moderna, tem denunciado em seus livros que a economia de mercado como modelo único de sociedade, tem sido danosa tanto para as economias nacionais quanto para o cotidiano dos indivíduos.

Segundo a Forrester (1997), a sociedade e as organizações não podem deixar que o desemprego seja apenas alvo de responsabilidade individual. A sociedade deve levar em conta os fatos reais, e, em vez de se esperar o "retorno do trabalho e do emprego" após a crise global, repensar em alternativas viáveis de resgate da dignidade humana. Segundo Araujo (2011), muitas empresas, diante deste cenário, têm optado por políticas de recursos humanos que visem a retenção e o desenvolvimento de profissionais capazes de atender às demandas de um mercado globalizado, aumentando a empregabilidade dos indivíduos.

Segundo Santos (1996), o mundo globalizado é caracterizado pela ausência de fronteiras, os lugares tendem a deixarem de serem locais para se tornarem mundiais, as pessoas adquirem maior capacidade e necessidade de mobilidade, as informações - econômicas, financeiras, políticas, sociais, culturais etc. - caminham em tempo real de uma parte do mundo à outra pelo "ciberespaço" (Lévy, 1997; Santos, 1996). Assim, o fenômeno global impacta seriamente as empresas, tornando-as cada vez mais sem pátria e seus produtos sem nacionalidade, o que contribui para o fenômeno que Levitt (1990, p.49) chamou de "homogeneização generalizada de gostos e preferências".

Dessa forma, a globalização forçou as organizações a se adaptarem a esse ambiente fluido, que acentua interdependência entre países, empresas e pessoas (Arrighi, 1996; Havery, 1992). Há uma dinâmica completamente nova, em um diferente sistema, caracterizada pela velocidade em que se movimentam os fluxos econômicos e fluxos informacionais (Santos, 1996). Em consequência, as empresas precisam ficar flexíveis (Harvey, 1992), fazendo da administração mais estratégica, capaz de absorver múltiplas tarefas, tornando-se: desindustrializada; 
geopolítica; espacial; efêmera; descentralizada; empreendedora etc., características de um tempo que Harvey classificou de "pós-modernidade flexível".

Muitos autores concordam que a internacionalização das organizações, em uma economia globalizada, é vital para garantir sua própria existência. As empresas que ficarem estagnadas, atuando em um pequeno recorte no espaço, incorrem no risco de perder mercado para a concorrência internacional que pode se instalar mais cedo ou mais tarde em sua praça (Kotabe e Helsen, 2000). Levitt (1990), em seu artigo clássico, A Globalização de Mercados, fornece um argumento para o avanço de organizações aos mercados estrangeiros. Segundo ele, as novas tecnologias de comunicação levam as pessoas a desejarem, em todos os lugares, as mesmas coisas. 0 mundo estaria se transformando em um mercado comum, no qual as pessoas desejam os mesmos produtos e o mesmo estilo de vida. Essa "convergência" crescente de necessidades e desejos favoreceria a comercialização de produtos globais, padronizados, capazes de gerar economias de escala e, simultaneamente, atrair e satisfazer os consumidores em vários mercados. Em sentido oposto, Kotler (1986) defende que a homogeneização dos mercados é um mito. Para o autor, a estratégia global acaba atingindo somente os consumidores que têm preferência por marcas ou produtos internacionalizados e alerta que a atuação em outros países implica na compreensão das necessidades próprias dos consumidores locais.

No atual cenário dos negócios, é fundamental para as organizações desenvolverem profissionais com as habilidades necessárias para atender as exigências desse mercado globalizado (Araujo, 2011; Danjou, 2002). Isto porque a competitividade, para a maioria dos negócios, deixa de ser local e se torna global (Arrighi, 2001; Forrester, 1997 e 2001; Santos, 1996). O ambiente se torna mais competitivo, obrigando as pessoas a conquistarem um espaço de forma cada vez mais feroz (Ransome, 1999). As organizações precisam estar sensíveis a este novo ambiente do mercado de trabalho. Dentro do possível, é preciso elaborar meios para enfrentar as manifestações da realidade de competitividade predatória, visando diluir e combater os efeitos negativos da globalização para os empregados e, sobretudo, visando garantir a convivência ética a todos agentes interessados, em especial os empregados e as organizações (Dalton et al., 1994; Jones, 1995).

\section{Um Novo Arranjo nas Relações de Trabalho}

Num passado recente, as relações de trabalho entre empregado e empregador eram caracterizadas por alguns princípios básicos, que implicavam principalmente em um emprego de longo prazo, pontuado por promoções ao longo da hierarquia de cargos e salários. Essas promoções, normalmente baseadas em senioridade (tempo de casa), eram o principal fator motivacional do funcionário e tinham uma relação direta com o conceito de progresso nessa forma tradicional de relacionamento. A nova lógica de mercado culminou com a ruptura desse contrato tradicional de trabalho (old deal), acabando com os princípios de reciprocidade e comprometimento de longo prazo e com as práticas de promoção e desenvolvimento (Cappelli, 1999; Sennett, 1999).

Empresas e funcionários estabelecem atualmente relações de curto prazo e com menor nível de comprometimento (Ransome, 1999). A efemeridade deste tipo de relacionamento tornou mais difícil para as empresas reterem seus empregados durante um longo período, sendo mais fácil buscar recursos no mercado para atender suas necessidades (Cappelli, 1999). Outro desafio dessa nova realidade é a de manter um mínimo de motivação e comprometimento por parte dos funcionários a fim de assegurar o nível do seu desempenho, já que não é mais possível utilizar a promoção com esse objetivo (pois a lógica não é mais um relacionamento de longo prazo) e os interesses dos funcionários ficam cada vez mais desvinculados com os da empresa (Cappelli, 1999). Na nova forma de relacionamento (new deal), os empregadores não detêm mais o controle, já que 


\section{A ética corporativa e o cenário competitivo: uma análise dos dilemas éticos nas relações de trabalho contemporâneas a partir do filme "0 Corte" (Le Couperet)}

este é fundamentalmente um acordo negociado entre o empregador e o empregado, sendo cada "vitória ou derrota" decorrente do poder de barganha de cada um deles em cada momento (Cappelli, 1999). Devido à já citada lógica de mercado de oferta e demanda, as empresas tiveram maior poder à época dos downsizings, quando a oferta de empregos estava escassa. Por outro lado, alguns funcionários passaram a ter maior poder de barganha na medida em que as suas habilidades tornaram-se mais importantes, raras e disputadas no mercado (Cappelli, 1999).

De uma forma geral, o que o new deal significa é uma noção implícita de que os empregadores não podem mais oferecer segurança no trabalho. Isso aponta para um declínio no desenvolvimento interno, já que não há uma garantia de retorno desses investimentos na medida em que o funcionário pode deixar a empresa a qualquer momento.

0 fim das relações tradicionais entre empregados e empregadores (old deal) trouxe diversos impactos para a forma como a carreira corporativa está estruturada. A lealdade em relação à organização foi substituída por uma grande ligação com a carreira, trazendo à tona o conceito de empregabilidade, no qual a responsabilidade pela carreira é do próprio empregado. Desta forma, os funcionários são encorajados a direcionar a sua atenção à gestão da carreira fora da empresa, já que têm poucas razões para identificarem-se especificamente com o cargo corrente, diante dessa visão de progressão profissional (Cappelli, 1999).

As mudanças nas relações de trabalho trouxeram novos arranjos nos chamados contratos de trabalho. Os contratos são acordos de troca entre empregados e empregadores. Além dos aspectos formais e escritos, como cartas de oferta de trabalho, acordos coletivos, negociações de sindicatos, entre outros, incluem também comunicações verbais, tais como promessas de treinamento, condições de trabalho, além de outras expressões de compromisso e intenções futuras (Rosseau, 1995).

De maneira geral, um contrato pode ser descrito como a crença de que existem obrigações entre duas ou mais partes. Obrigação é um compromisso de uma ação futura. No entanto, nem sempre fica claro o que esse compromisso significa exatamente e qual a extensão da mutualidade ou compromisso real entre as partes. Pessoas podem concordar com os mesmos termos mesmo quando sustentam diferentes pontos de vista. Contratos são voluntários compromissos são feitos livremente - e incompletos, de acordo com as fronteiras da racionalidade, cujos limites são estabelecidos pela busca de informação individual (Simon, 1976), e pelas mudanças no ambiente organizacional que tornam impossível especificá-los do início ao fim (Williamson, 1979). Tanto empregado quanto empregador são levados a preencher as lacunas e eles o fazem de maneira imprevisível. Esse caráter se acentua ainda mais nos dias de hoje devido à complexidade das relações de trabalhos e do ambiente que atuam as organizações (Harvey, 1992), fato que inviabiliza que todos os aspectos de um contrato sejam especificados e detalhados (Capelli, 1999).

Nesse sentido, observa-se que na prática os contratos se tornam auto-organizadores, ou seja, as pessoas trabalhando dentro de um contrato trabalham mais eficientemente e com menos supervisão do que se não houvesse nenhum contrato. Organizações em uma sociedade livre demandam comprometimento da força de trabalho. Organizações em ambientes turbulentos exigem contratos flexíveis o bastante para se transformar, sem quebrar. No entanto, uma vez criados, contratos tendem a resistir a revisões, fazendo a resposta a mudanças mais difícil (Rousseau, 1995).

Rousseau (1995) também nos alerta sobre a importância de se compreender as diferentes formas que os contratos podem se configurar em uma organização. Contratos são criados por promessas, confiança, aceitação e percepção de mutualidade. Os limites cognitivos, a limitação das informações e os diferentes quadros de referência fazem com que as pessoas tenham diferentes 
pontos de vista ao observar a existência e o significado dos contratos. Contudo, os contratos baseados em algum grau de mutualidade são a base da flexibilidade que emerge em organizações e empresas.

Para se entender os contratos contemporâneos mais profundamente, Rousseau (1995) afirma que é preciso entender as mudanças que ocorreram nos últimos anos: as práticas estabelecidas de trabalho se alteraram; algumas formas de contrato social disseminadas, como o emprego estável, se esvaíram e, por fim, as mudanças nas organizações reduziram a confiança entre empregados e empregadores.

\section{Ética Corporativa, Dilemas Éticos e o Cenário Competitivo}

A tarefa de adequar as organizações às exigências da sociedade contemporânea ainda é um desafio (Arrighi, 1996). A globalização dos mercados, acompanhada da mundialização das redes de negócios (Lévy, 1997), expõe as empresas e os indivíduos a uma árdua competição, onde, em um olhar mais macro, competem para obter mais clientes e mercado, e em um olhar mais micro, competem na obtenção e manutenção de seus empregos (Harvey, 1992). Nesse contexto, observa-se um ambiente quase que "predador", no qual é válida a utilização de quaisquer recursos para defesa dos seus interesses.

Para mediar o conflito de interesses entre os públicos e moldar comportamentos, a adoção de algumas estratégias organizacionais tornou-se necessária, sendo a ética corporativa reconhecida como uma importante ferramenta para lidar com a competitividade.

O Gale Dictionary of Psychology define ética como regras de comportamento baseadas em crenças sobre como as situações deveriam ser (Mott, 2001). Para Mott (2001), os sistemas de ética são conjuntos de regras de comportamento aceitável, e diz respeito ao que "se deve fazer" e "não se deve fazer" da vida, aos princípios e valores nos quais as relações humanas são baseadas. Enquanto, a moral é composta pelas crenças e valores que determinam as regras de comportamento, estando relacionada ao pensamento e ações do cotidiano.

No contexto das organizações, estudiosos como Carroll (1996) e Srour (2000) diferenciaram os conceitos de ética e moral da seguinte forma:

Quadro 1: Diferenças entre os Conceitos de Moral e Ética

\begin{tabular}{|l|l|}
\hline \multicolumn{1}{|c|}{ MORAL } & \multicolumn{1}{|c|}{ ETICA } \\
\hline $\begin{array}{l}\text { Doutrina ou sistema de conduta, relacionada à } \\
\text { conduta dos indivíduos e sociedade, código de } \\
\text { conduta adotado por determinado grupo ou } \\
\text { coletividade. }\end{array}$ & $\begin{array}{l}\text { Diz respeito à disciplina teórica, ao estudo sistemático } \\
\text { destes comportamentos, ligada com a disciplina formal } \\
\text { de estudos. }\end{array}$ \\
\hline $\begin{array}{l}\text { Conduta moral refere-se àquilo que está } \\
\text { relacionado aos princípios de certo e errado no } \\
\text { comportamento do indivíduo, grupo ou sociedade. }\end{array}$ & $\begin{array}{l}\text { Toda disciplina que lida com o que é bom e mau, e com } \\
\text { os deveres e obrigações morais, }\end{array}$ \\
\hline $\begin{array}{l}\text { Está associada a um conjunto de valores e regras de } \\
\text { comportamento aceitável esperado }\end{array}$ & $\begin{array}{l}\text { Pode ser observada como um conjunto de princípios e } \\
\text { valores morais }\end{array}$ \\
\hline $\begin{array}{l}\text { Corresponde a um conjunto de normas que as } \\
\text { práticas cotidianas deveriam seguir. }\end{array}$ & $\begin{array}{l}\text { Opera na reflexão e indagação, no estudo dos costumes } \\
\text { e das morais. }\end{array}$ \\
\hline
\end{tabular}

Fonte: Os autores baseados em Carroll (1996) e Srour (2000).

Esta separação de domínios da ética e da moral torna clara a definição da Ética Corporativa, estabelecendo terrenos bem distintos entre o que é praticada na vida organizacional, a moral, 
e a ética em seu estudo como disciplina.

Os termos: Ética Corporativa, Ética Empresarial ou Ética nos Negócios são encontrados nos livros e na literatura sobre o tema em questão, e podem ser utilizados indistintamente. Como já foi visto na definição de moral e ética, a Ética Corporativa é a disciplina teórica que estuda as crenças, valores e regras, ou seja, a moral que molda os comportamentos de indivíduos e grupos dentro da organização (Srour, 2000).

A Ética Corporativa significa estudar e tornar compreensível a moral vigente nas empresas contemporâneas, lembrando que o contexto ambiental e cultural exerce forte influência nessa moral (Srour, 2000). Nesse sentido, a Ética Corporativa está preocupados com os comportamentos - bons e maus, certos e errados - que surgem no contexto organizacional (Carroll, 1996; Victor e Cullen, 1988).

Com uma abordagem mais ampla, a definição do Ethics Resource Center (Vogl, 2000) acrescenta que a Ética Corporativa é vista abraçando tudo que impacta no modo como os stakeholders - shareholders, alta direção, gerência, empregados, clientes, fornecedores, comunidades e sociedade como um todo - percebem o comportamento da organização.

0 princípio da ética nos negócios é um conceito, um guia ou uma regra que, se aplicada quando o indivíduo se depara com um dilema ético, irá auxiliá-lo na tomada de decisão ética (Carroll, 1996). Vários princípios éticos, desenvolvidos no decorrer de séculos, foram organizados por filósofos e eticistas que levantaram a questão do que constitui o princípio da Ética nos Negócios e como deve ser aplicado.

Os princípios filosóficos da ética podem ser instrumentos importantes para a tomada de decisão nas empresas, pois esses princípios se baseiam em fundamentos sólidos que servem de justificação para que um indivíduo assuma um determinado comportamento. Existem quatro grandes abordagens de princípios filosóficos da ética, que Carroll (1996) e Ferrell, Fraedrich e Ferrell (2001) sintetizaram conforme é apresentado a seguir.

Quadro 2: Abordagens de Princípios Filosóficos da Ética

\begin{tabular}{|c|c|c|}
\hline ABORDAGENS & PRINCÍPIOS & DESCRIÇÃO \\
\hline $\begin{array}{l}\text { ABORDAGEM } \\
\text { TELEOLÓGICA } \\
\text { Refere-se às } \\
\text { filosofias morais } \\
\text { baseadas nos } \\
\text { resultados e } \\
\text { consequências das } \\
\text { ações tomadas, ou } \\
\text { seja, estudam o } \\
\text { valor moral do } \\
\text { comportamento } \\
\text { adotado avaliando } \\
\text { as suas } \\
\text { consequências. }\end{array}$ & Egoísmo & $\begin{array}{l}\text { Segundo o princípio do egoísmo, o comportamento certo ou aceitável é } \\
\text { medido em termos das consequências para os indivíduos. Assim, o } \\
\text { egoísmo afirma que "os indivíduos devem agir de modo a promover o } \\
\text { maior bem para eles mesmos". Uma vez que o princípio do egoísmo } \\
\text { promove o interesse pessoal e bem-estar próprio acima do interesse } \\
\text { comum, é considerado como uma corrente que classifica comportamentos } \\
\text { não éticos. Há, entretanto, o egoísmo esclarecido, ou seja, são ações que } \\
\text { mesmo visando o interesse próprio em longo prazo, promovem o bem- } \\
\text { estar dos demais. } \\
\text { Segundo o princípio utilitarista, a justiça e correção de uma ação podem } \\
\text { ser determinadas ao se observar seus resultados ou consequências na } \\
\text { maximização da utilidade para o maior número de pessoas. Deste modo, o } \\
\text { utilitarismo afirma que "os indivíduos devem agir de modo a produzir o } \\
\text { resultado que traga o melhor benefício para a maioria". Os principais } \\
\text { filósofos que defenderam o princípio utilitarista foram Bentham (1748- } \\
\text { 1832) e Stuart Mill (1806-1874). } \\
\text { 0 utilitarismo faz a organização pensar no bem-estar de todos os seus } \\
\text { stakeholders. Além disso, faz com que o indivíduo não pense na decisão } \\
\text { como boa ou ruim, mas sim como aquela que melhor se adapta à situação } \\
\text { visando o bem-estar da maioria. O ponto fraco do utilitarismo é } \\
\text { justamente ignorar ações inerentemente erradas, pois focando no fim, nos }\end{array}$ \\
\hline
\end{tabular}




\begin{tabular}{|c|c|c|}
\hline & Utilitarismo & resultados, os meios utilizados para atingir tal fim são esquecidos. \\
\hline $\begin{array}{c}\text { ABORDAGEM } \\
\text { DEONTOLÓGICA, } \\
\text { estuda o valor } \\
\text { moral do } \\
\text { comportamento em } \\
\text { si e os meios para } \\
\text { alcançá-los, e não as } \\
\text { consequências. } \\
\text { A deontologia foi } \\
\text { muito influenciada } \\
\text { por Kant. }\end{array}$ & $\begin{array}{c}\text { Princípio } \\
\text { dos Direitos }\end{array}$ & $\begin{array}{l}\text { O princípio dos direitos considera que existem ações moralmente erradas } \\
\text { e, portanto, não aceitáveis sob qualquer pretexto (por exemplo, matar } \\
\text { uma pessoa) e que todos os indivíduos possuem direitos básicos e } \\
\text { absolutos que não podem ser violados, nem mesmo por uma ação de } \\
\text { maximização de utilidade. Um direito básico só pode ser suprimido por } \\
\text { outro direito mais básico ainda. São direitos básicos: o direito à vida, à } \\
\text { liberdade de consciência, de consentimento, de privacidade, à liberdade } \\
\text { de expressão, de processo legal justo. } \\
\text { o princípio dos direitos considera determinados comportamentos } \\
\text { inerentemente certos e expressa à moralidade do ponto de vista do } \\
\text { indivíduo ou de grupo de indivíduos. Assim, força que "o indivíduo se } \\
\text { pergunte em sua tomada de decisão pessoal o que é devido a ele para } \\
\text { promover o bem-estar dos indivíduos". A dificuldade do princípio dos } \\
\text { direitos é determinar qual direito prevalece sobre o outro e quais } \\
\text { condutas são inquestionavelmente corretas. }\end{array}$ \\
\hline \begin{tabular}{|} 
ABORDAGEM DA \\
JUSTIÇA \\
Do mesmo modo \\
que o utilitarismo \\
não lida com a idéia \\
dos direitos do \\
indivíduo, também \\
não toca no ponto \\
da justiça. Esta \\
abordagem se \\
baseia no \\
tratamento justo de \\
cada indivíduo e \\
avalia a natureza \\
ética com base na \\
eqüidade.
\end{tabular} & $\begin{array}{l}\text { Princípio da } \\
\text { Justiça }\end{array}$ & $\begin{array}{l}\text { Há vários tipos de justiça para se avaliar a eqüidade: } \\
\text { Justiça Distributiva baseia-se na avaliação das consequências ou dos } \\
\text { resultados analisando os benefícios obtidos e a eqüidade nas } \\
\text { recompensas. } \\
\text { Justiça Processual refere-se aos processos e atividades que geram } \\
\text { consequências ou resultados, tais como o processo, acordos e práticas de } \\
\text { tomada de decisão justa. Justiça Compensatória envolve compensar o } \\
\text { indivíduo por uma injustiça passada. } \\
\text { A principal corrente desta abordagem é o princípio da justiça, } \\
\text { apresentado por Rawls. O princípio da justiça, de Rawls, apresenta a idéia } \\
\text { de que é necessário, primeiramente, ter um método justo pelo qual o } \\
\text { indivíduo possa escolher os princípios através dos quais os conflitos serão } \\
\text { resolvidos. Os dois princípios de justiça que acompanham esta teoria são: } \\
\text { que todas as pessoas têm iguais direitos e, portanto, todas devem ser } \\
\text { tratadas com igualdade; e no caso de desigualdades sociais e econômicas, } \\
\text { o indivíduo com menor vantagem deve ser resguardado para que não seja } \\
\text { tirado proveito de sua situação de desvantagem. } \\
\text { Assim, o princípio da justiça preserva os valores básicos de liberdade, } \\
\text { igualdade de oportunidade e preocupação com os desfavorecidos, que se } \\
\text { enraizaram nas crenças morais. }\end{array}$ \\
\hline \begin{tabular}{l} 
ABORDAGEM DA \\
\multicolumn{1}{c}{ ÉTICA DA } \\
VIRTUDE \\
A ética da virtude é \\
um r sistema \\
centrado "no ser \\
humano e em \\
humano".
\end{tabular} & & $\begin{array}{l}\text { Todas as abordagens e princípios citados anteriormente são orientados } \\
\text { para uma ação, isto é, são desenhados para guiar as atitudes e decisões } \\
\text { individuais. Concentram-se no fazer e em ações e deveres. Porém, a mais } \\
\text { antiga tradição filosófica da ética, cuja raiz está no pensamento de } \\
\text { Aristóteles, refere-se à ética da virtude, focalizando o indivíduo imbuído } \\
\text { com certas virtudes - honestidade, justiça, confiança, benevolência - que } \\
\text { refletem o que o indivíduo é e, por consequência, como ele agirá e tomará } \\
\text { decisões diante dos dilemas. Parte do pressuposto de que os indivíduos } \\
\text { possuem recursos internos para viver de forma virtuosa, focando na } \\
\text { questão de "qual tipo de pessoa eu sou ou deveria me tornar". }\end{array}$ \\
\hline
\end{tabular}

Fonte: Os autores baseados em Carroll (1996) e Ferrell, Fraedrich e Ferrell (2001).

No cenário competitivo e globalizado, esta ética do trabalho cada dia mais se fundamenta nos 
princípios que regem a lógica do capitalismo na sociedade moderna onde conforme coloca Comte-Sponville (2005) o capitalismo tenta buscar o que é mais eficiente e mais lucrativo. Segundo o autor, o capitalismo não é moral, ele não funciona para a virtude, para a generosidade ou o para o desinteresse, mas, ao contrário, ele está voltado para o interesse pessoal ou familiar, isto é, o capitalismo funciona para o egoísmo (que faz parte dos direitos do homem), para criar a riqueza. Comte-Sponville (2005) considera que o capitalismo não é, portanto, nem moral nem imoral: ele é amoral, dando ao prefixo "a" seu sentido puramente privativo (de privação) onde não se pode contar com o mercado para ser moral no seu lugar, nem com a moral para criar riqueza.

Por fim, conforme coloca Lópes Ruiz (2004) fomenta-se hoje no ambiente corporativo a prática do aumento da empregabilidade do indivíduo, (...) uma ética do trabalho individualizado segundo a qual se espera que cada indivíduo se comporte como se ele estivesse conduzindo seu próprio negócio dentro de um negócio maior, que se sinta dono (ou sócio) da empresa na qual trabalha, que pense em seu trabalho como um produto ou serviço a ser vendido. Trata-se de uma ética do trabalho empresarial (do trabalho entendido em termos de "empreendimento") que o orienta e estimula para atuar como seu próprio chefe, para assumir plena responsabilidade pela direção de sua própria "empresa" (geralmente, sua carreira), para se pensarem como "proprietário de si", de suas capacidades, destrezas e talentos, para estar disposto a investir neles e empreender constantemente novos desafios. Lópes Ruiz (2004, p. 327)

\section{A Produção Cinematográfica como um Recurso para a Análise de Fenômenos Sociais}

A indústria de cinema surgiu e cresceu até se tornar uma popular mídia de massa. Os estúdios em Hollywood são hoje os maiores produtores de filmes no mundo. Para Brito (apud Araujo e Chauvel, 2008), eles fabricam "risos e lágrimas" e os transformam em produtos destinados à tela. O produto filme funciona como um forte veículo de mídia, trazendo desde entretenimento até informações históricas e críticas sobre a sociedade e a humanidade. 0 hábito de assistir a filmes no cinema, bem como em outros canais de exibição, tornou-se, então, muito popular na sociedade contemporânea. Filmes são produtos culturais e, portanto, enraizados em realidades, tradições, "redes de significados" (Geertz, 1973).

Filmes são também produtos hedonistas, que prometem diversão e a possível realização de fantasias (Shimp, 2002), mexem com os sentidos, com os sonhos e com processos inconscientes (Baudry, 1974), prometendo aos espectadores uma experiência capaz de tocar no seu cotidiano e no seu imaginário.

A decisão de assistir a um filme está relacionada com uma gama de pulsões, tais como moda, novidade, fruição de ícones ou signos valorizados pelas pessoas no seu contexto social. Diante da influência dessa indústria sobre os costumes, os hábitos, a moral e o consumo, muitos estudiosos têm observado a produção cinematográfica como uma importante ferramenta para análise de importantes temas contemporâneos (Holbrook, 1999). A utilização do recurso de obras de cinema não é uma novidade em ciências humanas. Na área de Administração o recurso ainda é pouco explorado, todavia se observa um crescente aproveitamento de filmes como recurso didático no ambiente acadêmico, esse fenômeno ocorre, pois segundo Araujo e Chauvel (2008), os filmes abordam questões socialmente relevantes como história, política, cultura etc., fato que pode despertar no espectador maior capacidade de interpretação e compreensão de fenômenos sociais a partir da experiência de ambiente que se desenvolve o filme e, também, da experiência vivida pelos personagens. 
No que diz respeito ao presente estudo, é interessante observar que ao longo das duas últimas décadas vários filmes exploram a questão da competitividade excessiva. Esse fenômeno não é restrito aos documentários e aos filmes que por sua essência procuram fazer a crítica e a reflexão sobre a realidade, tais como The Corporation, 2003; Super Size Me, 2003. Mas, também diversas obras ficcionais lançaram seu olhar crítico ao ambiente organizacional, denunciando, em alguma medida, comportamentos nocivos que se tornam recorrentes. Na realidade do mundo contemporâneo, a competitidade excessiva nas interações humanas é praticamente uma primazia, onde o importante é conseguir alcançar determinados resultados ou obter determinadas vantagens. Essa competitividade predatória muitas vezes entra em rota de colisão com valores internalizados pela sociedade, e convergem suas críticas para o papel das lideranças na socialização dessas práticas e comportamentos conforme observado no filme "O Diabo Veste Prada" (Tomei e Hilal, 2006).

Filmes como Nascido para Matar (Full Metal Jacket, 1987), O Closet (Le Placard, 2001), Legalmente Loira (Legally Blonde, 2004), Em Boa Companhia (In Good Company, 2004), O que você Faria? (El Método, 2005), o Corte (Le Couperet, 2005), O Diabo Veste Prada (The Devil Wears Prada, 2006), A Caixa (The Box, 2009), Amor sem Escalas (Up in the Air, 2010) são alguns exemplos de produções que têm em comum uma representação das diferentes inserções do indivíduo nas organizações e suas relações de trabalho - tema que, também no ambiente acadêmico, gera reflexões e debates.

Os filmes, assim como outras formas de expressão artística, são veículos que retratam a cultura e as visões vigentes. Portanto, crenças e valores codificados por meio das imagens da narrativa são representativos da cultura que produz e consome esse tipo de produção artística. Ou, nas palavras de Hirschman e Stern (1994): "o consumo de imagens cinematográficas tem um poderoso efeito sobre a imagem que mulheres e homens têm de si mesmos, seus papéis, seu lugar" (p. 580). Nesse sentido, os filmes podem ser um importante recurso metodológico para análise de fenômenos sociais, representando uma rica fonte de material para pesquisa com relevante importância ao pensamento acadêmico.

\section{Aspectos Metodológicos}

O presente estudo adotou o método de análise qualitativa de imagens em movimento (Rose apud Bauer e Gaskell, 2008). De acordo com Loizos (apud Bauer e Gaskell, 2008, p.108), “... o visual e a mídia desempenham papéis importantes na vida social, política e econômica. Eles não podem ser ignorados", uma vez que as produções de audiovisual por meio das representações e significações são capazes de influenciar ou refletir um alguma realidade em um determinado contexto.

Neste estudo, optou-se por analisar a produção audiovisual $O$ Corte (Le Couperet, 2005). 0 filme traz a empresa como cenário de fundo das relações pessoais e retrata um contexto de avanço da globalização, da competitividade, das reestruturações produtivas, apresentando a reação do profissional frente a esse novo cenário organizacional. A escolha deste corpus de análise deveu-se ao fato de a produção cinematográfica ser testemunhada no âmbito social e cultural, desempenhando uma função social por meio de suas narrativas. Ao estreitar as relações entre cinema e sociedade, a denominada "sétima arte" chega a exprimir o reflexo das crenças e valores dominantes de determinada cultura (Turner, 1997).

Conforme proposto por Rose (apud Bauer e Gaskell, 2008), a análise de imagens em movimento começa pela seleção de uma amostragem. As imagens selecionadas seguem para um referencial de codificação. Por fim, devem-se transcrever as informações visuais ou verbais da amostragem, visando-se obter uma padronização da análise. Neste estudo, optou- 


\section{A ética corporativa e o cenário competitivo: uma análise dos dilemas éticos nas relações de trabalho contemporâneas a partir do filme "0 Corte" (Le Couperet)}

se por realizar uma descrição do filme nas sequências (S), que foram numeradas e as informações visuais e verbas são descritas em forma de texto. Sequências são unidades narrativas, que podem ser determinadas por um corte, uma alteração de plano, um novo cenário, a entrada de novos personagens ou mudanças na trilha sonora (Passarelli, 2004). Reuni-se ao total de vinte e duas sequências. Realizou-se, no início da próxima sessão, uma breve análise da descritiva do filme, tendo por fim uma contextualização entre o filme e a temática em análise, destacando passagens específicas e transcrevendo as falas dos personagens sempre que a narrativa corroboram com os temas discutidos neste estudo. Por fim, realiza-se uma análise do conteúdo reunido a partir do cotejo entre a problemática apontada pelo material audiovisual e o respectivo debate da temática na literatura acadêmica.

O estudo se propôs a obter algumas percepções sobre o impacto que ambientes competitivos produzem na organização, observando os dilemas éticos que são impostos aos profissionais que vivenciam o atual cenário de grande competitividade. Para realizar essa análise, optou-se fazer uma comparação entre fenômenos comportamentais ocorridos em uma produção cinematográfica que retrate ambientes competitivos, tanto do ponto de vista da organização quanto dos empregados.

Para a análise conceitual de como são retratados o contexto competitivo, os dilemas éticos, e os impactos das recentes mudanças no mercado de trabalho serão reproduzidos diferentes diálogos e sequencias relevantes identificados ao longo do filme.

\section{A Competitividade do Mercado Global com Base no Filme $O$ Corte}

A obra de análise oferece um retrato sutil sobre as mudanças ocorridas nas relações de trabalho nas últimas décadas, onde se observa o tratamento de choque dados aos trabalhadores devido à competitividade excessiva imposta pela globalização.

O filme apresenta uma situação típica do processo de globalização, pois parte da fusão de duas grandes corporações da indústria de papel, e repete uma sequencia de dilemas éticos decorrentes dessa decisão, mostrando alguns dos efeitos mais nocivos do avanço da globalização dos mercados e explorando o contexto de alta competitividade nas empresas e, consequentemente, nos indivíduos. $O$ Corte permite ao espectador o contato com os desafios enfrentados pelos trabalhadores nos dias atuais, como a restruturação dos processos produtivos, a qual promove mudança na estruturação da organização e, fatalmente, culmina em diminuição dos funcionários e, assim, em alta competitividade interna. Em outra frente, o filme explora a competitividade externa à organização, abordando questões como a dificuldade de recolocação no mercado de trabalho, o desafio de superar concorrentes mais jovens e com disposição para trabalhar por menores salários, a necessidade de readaptação profissional que geralmente leva a aceitação de atividades com menor remuneração etc. Essas e outras questões trazidas pelo filme vêm ao encontro de problemáticas que muitos estudiosos (Arrighi, 1996; Canclini, 2003; Forrester ,1997; entre outros) alertam como efeitos negativos da globalização vividos nos dias atuais.

Inicialmente, o filme mostra que a vida do personagem principal é transformada quando este é demitido do cargo que ocupava há 15 (quinze) anos. Assim sendo, o protagonista, personagem chamado de Bruno Davert - interpretado por José Garcia - é obrigado a mudar totalmente sua rotina depois que perde seu emprego. Casado e com dois filhos, Davert passa a enviar currículos constantemente a fim de conseguir uma nova oportunidade de trabalho. Todavia, após dois anos de procura, sem lograr êxito, este se torna uma pessoa amarga, hostil e antissocial. 
De forma inconsciente, o protagonista do filme culpa a competitividade do mundo contemporâneo pelo fato de não conseguir aceitação em nenhuma oportunidade a que se candidatou, entendendo que os outros lhe usurpavam o emprego. Bruno atinge seu limite quando concorre a uma vaga em uma empresa do ramo de papel e se depara com o candidato Raymond Machefer e começa a pensar que este havia tomado sua vaga. Depois disso, Bruno decidiu que deveria saber quantas pessoas qualificadas existem no mercado competindo com ele. Cria, para esse fim, uma empresa fictícia e uma caixa postal e toma uma decisão drástica: partir para guerra, isto é, eliminar ou "cortar" os seus potenciais concorrentes. Passa, então, a atrair as vítimas em potenciais anunciando oportunidades de emprego. Para tal, atribui aos candidatos "procurados" as qualificações que a vaga de Raymond Machefer exigia, visando identificar seus concorrentes. Ao analisar os currículos enviados fica com uma sensação de poder e superioridade por conhecer o segredo dos candidatos. Bruno Davert seleciona seus potenciais concorrentes e, após essa sequência, observa-se uma mudança em relação à lealdade para como a empresa na passagem abaixo:

Bruno Davert: Descobri que eles eram muitos ignorantes e cheios de vaidade. Metade dizia se importar com os acionistas. Mas os acionistas são nossos inimigos. Eles fazem milhares serem despedidos de empresas saudáveis para dar mais aos gananciosos.

Apenas cinco currículos sobram depois da análise, eram candidatos que tinham qualificação e experiência profissional que pareciam ser melhores ou tão boas quanto as suas.

Bruno Davert: Se eu matasse mil acionistas, não ganharia nada. Se eu matasse dez diretores que demitiriam mil funcionários, o que ganharia? Nada. Eles são meus inimigos, mas, não é problema meu. Aqueles cinco currículos era o meu problema. Aqueles cinco, mais Machefer.

Depois disso, Bruno Davert passa literalmente a executar os seus potenciais concorrentes para conseguir uma colocação no mercado de trabalho. Quando perseguia a terceira vítima, Etieene Barnet, Bruno Davert entra em um snack bar. No recinto, Davert se surpreende com o fato de seu concorrente está trabalhando como atendente no local, quando se inicia o seguinte diálogo:

Etieene Barnet: São tempos de criminalidade.

Bruno Davert: Como?

Etieene Barnet: Penso muito agora. É tudo que me resta como garçom. A sociedade vive uma era insana. Na antiga China para poupar alimento abandonavam bebês na montanha. Os esquimós deixavam os idosos morrerem nos icebergs. Mas nós nos livramos das pessoas quanto estão no auge da produção. É isso que acontece. É autodestruição.

Bruno Davert: Tem razão.

Etieene Barnet: Nós pagamos um preço alto para manter os idosos. Se deixarmos alguém morrer do calor do verão, do desânimo do outono, do frio do inverno ou pelo prazer da primavera salvaríamos a economia. Em vez disso, somos descartados.

Bruno Davert: Está deixando você maluco também?

Etieene Barnet: Com certeza. Faríamos tudo por um emprego...

Após atropelar e assassinar Etieene Barnet, Bruno reforça seu lado individualista e utilitarista 


\section{A ética corporativa e o cenário competitivo: uma análise dos dilemas éticos nas relações de trabalho contemporâneas a partir do filme "0 Corte" (Le Couperet)}

ao ressaltar suas qualidades e ao pensar que suas atitutes beneficiam sua família, já que com a eliminação dos "concorrentes" poderia conseguir um emprego e com isso voltaria a garantir a si próprio e a sua família a mesma qualidade de vida antes do desemprego.

Bruno Davert: Sempre fui um marido, um pai, um leal funcionário.

Todavia, esse terceiro assassinato desconcerta Davert, fato que o leva a se questionar em relação aos seus planos.

Bruno Davert: Deveríamos nos unir, não brigar por ninharia. Enquanto os diretores riem ou pior, não vê que existimos.

No quadro a seguir é apresentada a descrição do filme nas sequências (S). Tratam-se das unidades narrativas que são apresentadas cronologicamente nessa análise, determinadas por uma alteração de plano, um novo cenário, e/ou a entrada de novos personagens:

Quadro 3: Descrição do Filme $O$ Corte em Sequências (unidades narrativas)

\begin{tabular}{|c|l|}
\hline $\mathbf{S}$ & \multicolumn{1}{|c|}{ TEXTO } \\
\hline $\mathbf{1}$ & $\begin{array}{l}\text { Bruno Davert que ressalta suas qualidades após cometer um assassinato: } \\
\text { Bruno Davert: Sempre fui um marido, um pai, um leal funcionário. } \\
\text { Relembra um momento de reconhecimento na empresa do ramo de papel no qual trabalhou por 15 } \\
\text { anos. } \\
\text { Chefe: Por seus 15 anos de lealdade a empresa que também é sua, por favor, aceite este singelo } \\
\text { presente para registrar a qualquer momento suas idéias criativas que tanto ajudaram nossa } \\
\text { produtividade. }\end{array}$ \\
\hline $\mathbf{2}$ & $\begin{array}{l}\text { Bruno Davert, após seis meses, é demitido com mais } 600 \text { pessoas em razão de reestruturação } \\
\text { organizacional - uma mudança física da empresa para outro país. Ele recebeu uma indenização de } 15 \\
\text { salários e sentiu-se satisfeito por isso. } \\
\text { Chefe: Não estou preocupado com você, Bruno. Com sua capacidade, logo vai conseguir trabalho. }\end{array}$ \\
\hline $\mathbf{3}$ & $\begin{array}{l}\text { Bruno, após dois anos não conseguiu outro emprego, quase quitou a prestação do carro, possuía 15 } \\
\text { anos de hipoteca de sua casa, uma mulher, Marlene, e dois filhos, Máxime e Betty, para criar. Bruno } \\
\text { tem consciência que não é o único a procurar emprego, que há candidatos mais sensuais, fortes e } \\
\text { mais sorridentes e relaxados. Ao assistir o comercial da fábrica Arcadia, também no ramo de papel, } \\
\text { se depara com o personagem Raymond Machefer e começa a pensar que o mesmo havia pegado sua } \\
\text { vaga. }\end{array}$ \\
\hline $\mathbf{4}$ & $\begin{array}{l}\text { Bruno decidiu que deveria saber quantas pessoas qualificadas existem no mercado competindo com } \\
\text { ele. } \\
\text { Cria então uma empresa fictícia e uma caixa postal requerendo às qualificações que a vaga de } \\
\text { Machefer exigia. Começa a analisar os currículos enviados e tem uma sensação de poder e } \\
\text { superioridade em conhecer o segredo de seus concorrentes, observamos uma mudança à lealdade a } \\
\text { empresa na passagem abaixo: } \\
\text { Bruno Davert: Descobri que eles eram muito ignorantes e cheios de vaidade. Metade dizia se importar } \\
\text { com os acionistas. Mas os acionistas são nossos inimigos. Eles fazem milhares serem despedidos de } \\
\text { empresas saudáveis para dar mais aos gananciosos. } \\
\text { Cinco currículos sobram após a análise, eram candidatos que tinham diplomas, carreira e } \\
\text { experiência que pareciam se não melhor, tão bons quanto o Bruno. } \\
\text { Bruno Davert: Só cinco. }\end{array}$ \\
\hline
\end{tabular}




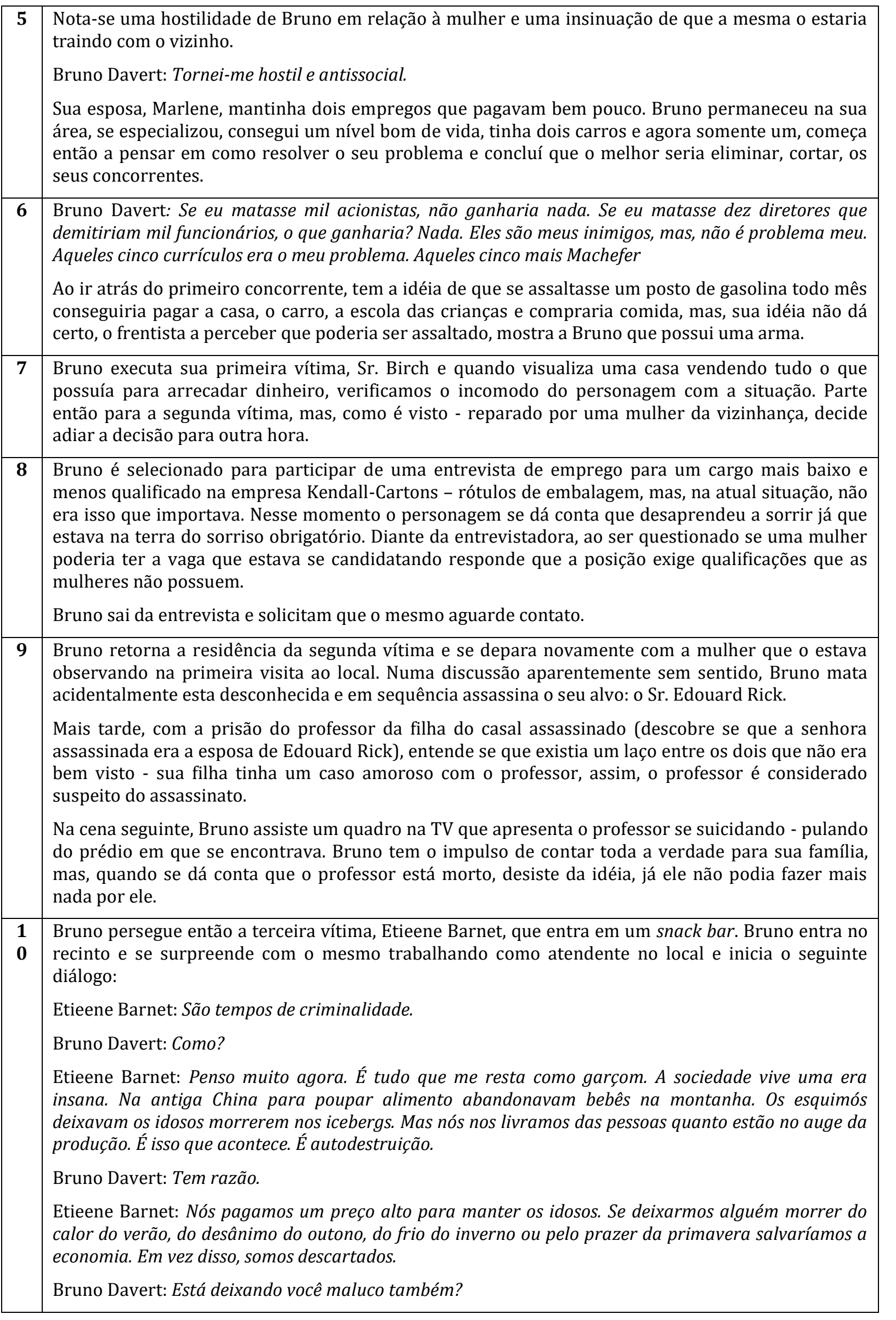




\section{A ética corporativa e o cenário competitivo: uma análise dos dilemas éticos nas relações de trabalho contemporâneas a partir do filme "O Corte" (Le Couperet)}

\begin{tabular}{|c|c|}
\hline & $\begin{array}{l}\text { Etieene Barnet: Com certeza. Faríamos tudo por um emprego... } \\
\text { Etieene Barnet: Mas, não pode enfrentar o avanço do capitalismo. } \\
\text { Bruno Davert: O que deveríamos fazer? } \\
\text { Etieene Barnet: Deveríamos... Mais um pouco de vinho? } \\
\text { Bruno Davert: Não. } \\
\text { Etieene Barnet: Tornar os seres humanos o centro de tudo. Mas é tarde demais. }\end{array}$ \\
\hline $\begin{array}{l}1 \\
1\end{array}$ & $\begin{array}{l}\text { Voltamos ao início do filme aonde Bruno acaba de atropelar Barnet e relembra sua lealdade à } \\
\text { empresa e à família. Percebemos o quanto esse assassinato, após este diálogo, desconcerta Bruno } \\
\text { que diz para si mesmo: Deveríamos nos unir, não brigar por ninharia. Enquanto os diretores riem ou } \\
\text { pior, não vê que existimos. } \\
\text { Após essa reflexão, Bruno pensa em se matar. Mas, não consegue, e adormece. }\end{array}$ \\
\hline $\begin{array}{l}1 \\
2\end{array}$ & $\begin{array}{l}\text { Bruno justifica o carro amassado, devido ao atropelamento, batendo em outro veículo. Direciona-se } \\
\text { para uma oficina mecânica onde se passa o seguinte diálogo: } \\
\text { Técnico da oficina: Temos de nos unir. Posso ser o próximo. } \\
\text { Bruno Davert: Você é essencial aqui. } \\
\text { Técnico da oficina: Somos três, eu sou o mais velho, então vou primeiro. } \\
\text { Bruno Davert: Você tem mais experiência. } \\
\text { Técnico da oficina: Mais, sou o mais caro. Se eu perder o emprego, vou lá pra cima e estouro meus } \\
\text { miolos na frente do meu chefe. } \\
\text { Bruno Davert: E por que não acabar com os outros dois? Sem que ninguém saiba? } \\
\text { Técnico da oficina: Ninguém saiba? (Risos) }\end{array}$ \\
\hline & $\begin{array}{l}\text { Esta sequência rápida foca a visita de Bruno e sua mulher Marlene, numa clínica onde eles iniciam } \\
\text { uma terapia de casal, visto que o comportamento de Bruno é considerado estranho, "ele não é mais o } \\
\text { mesmo". }\end{array}$ \\
\hline $\begin{array}{l}1 \\
4\end{array}$ & $\begin{array}{l}\text { Bruno vai a Arcadia observar Raymond Machefer, no cargo que seria o ideal para ele, e executa sua } \\
\text { quarta vítima, Sr. Krantz. }\end{array}$ \\
\hline & $\begin{array}{l}\text { Ao procurar a quinta vítima, Bruno descobre que a mesma encontra-se empregada no ramo de } \\
\text { papéis. }\end{array}$ \\
\hline & $\begin{array}{l}\text { Há uma interrupção na série de assassinatos devido à prisão de seu filho, Máxime, acusado de } \\
\text { roubar softwares. Para inocentar o filho, Bruno confirma suas mentiras e elimina as provas do roubo } \\
\text { com a ajuda de sua esposa e filha. A família fica orgulhosa da atitude de Bruno e o elogia. }\end{array}$ \\
\hline $\begin{array}{l}1 \\
7\end{array}$ & $\begin{array}{l}\text { Temos a visita de dois agentes a casa de Bruno. Inicialmente supõe-se que a visita é devida à prisão } \\
\text { de Máxime. Ao longo da cena o telespectador entende que os agentes estão realizando uma } \\
\text { investigação devido à morte dos profissionais no ramo de papel industrial que também passaram } \\
\text { pela entrevista da empresa Kendall-Cartons. Estes profissionais alertam Bruno que está havendo } \\
\text { uma série de assassinatos de pessoas que foram ligadas ao ramo, e que ele poderia estar correndo } \\
\text { perigo. }\end{array}$ \\
\hline & $\begin{array}{l}\text { Bruno retorna aos correios para verificar sua caixa postal em nome da empresa fictícia e se } \\
\text { surpreende: depara com novos currículos e um potencial concorrente. Marca a entrevista para } \\
\text { observar o candidato, visto que o currículo não dá subsídios de onde mora - assim, quando ninguém } \\
\text { aparece para entrevistar, Hutchinson vai embora e Bruno o segue. O encontra como um vendedor de } \\
\text { roupas, ternos masculinos. } \\
\text { Ao conversar com Gerard Hutchinson, descobre que o candidato enfeitou o currículo e que não era } \\
\text { realmente um concorrente em potencial por estar afastado a cinco anos do negócio; havia sido } \\
\text { abandonado pela esposa e se encontrava fracassado. Bruno desiste de matá-lo. }\end{array}$ \\
\hline 1 & me expõe uma questão de prova realizada \\
\hline
\end{tabular}




\begin{tabular}{|l|l|}
\hline $\mathbf{9}$ & para o colégio, quando a família entra em um debate ético: \\
& Máxime: "Os fins justificam os meios?" \\
Marlene: O que acha? & $\begin{array}{l}\text { Máxime: Não justificam os meios. } \\
\text { Betty: Menos para tirar o filho da cadeia. } \\
\text { Marlene: Deixe-o em paz. Você disse mais alguma coisa? } \\
\text { Máxime: Eu disse: "menos em tempo de guerra." } \\
\text { Betty: Na verdade, a escolha dos meios é um luxo de uns poucos privilegiados. }\end{array}$ \\
$\mathbf{2}$ & $\begin{array}{l}\text { Bruno invade a casa de Raymond Machefer, pega no sono e se depara com o mesmo apontando uma } \\
\text { arma. } \\
\text { Ele consegue reverter à situação esclarecendo para Manchefer quem ele é e quanto o admira. }\end{array}$ \\
\hline $\mathbf{2}$ & $\begin{array}{l}\text { Ele afirma que está em busca de ajuda e conselhos para voltar ao mercado de trabalho. Machefer } \\
\text { está bêbado e o leva para a cozinha para beberem juntos, e acaba pegando no sono. Bruno consegue } \\
\text { matar Manchefer. Ele sai da casa e deixa aberto o gás da cozinha. Manchefer acende um cigarro ao } \\
\text { acordar, e a casa explode. }\end{array}$ \\
\hline $\mathbf{2}$ & $\begin{array}{l}\text { Bruno Davert consegue a vaga na Arcádia. O caso dos assassinatos em série dos profissionais de } \\
\text { papéis é "solucionado" com o suicídio de Gerard Hutchinson - que foi considerado pela polícia como } \\
\text { um fracassado psicopata. }\end{array}$ \\
\hline
\end{tabular}

Fonte: Os autores.

\section{As Relações de Trabalho com Base no Filme 0 Corte}

$O$ filme $O$ Corte chama ao centro do debate alguns dos resultados mais nocivos da alta competitividade. 0 ambiente de trabalho inóspito, a competição sem limites, a falta de valores éticos ou a "desconsideração" destes, que podem resultar em patologias psicossociais típicas de nosso tempo. Do ponto vista didático, esse filme da mesma forma que as denúncias feitas em alguns livros (Forrester, 1997; 2001), passa uma importante mensagem ao mundo contemporâneo, qual seja, é preciso questionar o excesso de competitividade imposto pela economia de mercado, reconhecendo os seus efeitos indesejáveis, e buscando formas que ressaltem a necessidade da convivência ética entre as pessoas, estejam elas inseridas na sociedade em geral, ou inseridas no contexto organizacional.

Cea e Zen (2008) analisam o filme "O Corte" sob o enfoque das consequências das atuais transformações no mundo do trabalho e do dilema da responsabilização pelo desemprego e identificam alguns pontos fundamentais para essa análise:

"Das mensagens que a obra nos deixa, duas merecem atenção especial. A primeira diz respeito ao ideário, já consensual nesta sociedade, de que o desemprego é um problema individual, e deve ser, portanto, individualmente resolvido. A segunda mensagem, subliminarmente presente no filme, aponta a solução para o desemprego numa direção oposta: o problema não está no indivíduo, mas no sistema. E este só coletivizará as oportunidades se, numa perspectiva transformadora, tornar o homem o centro de tudo.

$\cdots$

O resultado mais brutal destas transformações foi a expansão, sem precedentes na era moderna, do desemprego estrutural, que atinge o mundo em escala global, sendo a consequência social mais impactante das mudanças econômicas e políticas em curso. Como estratégia ideológica mais evidente, o pensamento (neo) liberal burguês produziu o preceito de que a posição dos indivíduos no mercado de trabalho é imediatamente definida pelos méritos individuais, para os quais seria 


\section{A ética corporativa e o cenário competitivo: uma análise dos dilemas éticos nas relações de trabalho contemporâneas a partir do filme "0 Corte" (Le Couperet)}

determinante a qualidade de seus atributos, a gama de seus conhecimentos e a eficácia real de suas capacidades pessoais.

No filme de Costa-Gravas, tal ideário é posto a nu. Se em outras fases do modo capitalista de produção as mudanças no modo de produzir resultaram mais danosas aos trabalhadores com níveis de qualificação inferiores, o atual modelo consegue dar-se ao luxo de também dispensar trabalhadores altamente qualificados, como é o caso do protagonista do filme." (Cea e Zen, 2008, p. X).

Quando Bruno Davert internalizou que "o desemprego é um problema individual, e deve ser, portanto, individualmente resolvido", ele começou a re-analisar o seu contrato psicológico, a sua empregabilidade, os seus méritos individuais e qualificações.

Essas constatações individuais projetadas nas relações sociais levam a indução do pensamento de que "o problema não está no indivíduo, mas no sistema". Nesse sentido, o sistema conduz a visão de negócios baseada na guerra, na qual a competição se resume em aniquilar o adversário e a organização é apenas um meio para vencer a guerra. Vale mais a competitividade e o "vencer a qualquer custo", do que preservar valores como confiança e credibilidade. Não importa em que organização se trabalha, já que o importante é vencer. E, nessa visão triunfalista individual, os interesses dos funcionários se tornam cada vez mais desvinculados dos objetivos organizacionais. Para Kanter (1997, p.331), "se as pessoas são encorajadas a contar consigo mesma, como então a corporação pode contar com elas?".

Bruno Davert sabe que seu desenvolvimento profissional não será assegurado, patrocinado e/ou reconhecido pela organização. 0 "conhecimento específico da empresa", proveniente de uma longa experiência na organização, perde importância em relação a um conhecimento mais geral. A segurança do funcionário vem do fato de se construir a chamada empregabilidade, sendo elaborada a partir do acúmulo de habilidades (obtidas em experiências diversas) e da reputação (gerada por uma produção vista como de qualidade e que se torne perceptível em um curto espaço de tempo). A empregabilidade é, assim, um capital individual que pode ser investido em novas oportunidades à medida que elas surgem (dentro ou fora da empresa). Nesse sentido, os indivíduos têm mais estímulos para produzi-lo do que para desenvolver o capital organizacional, que advém, por exemplo, do aprender bem um sistema e atender às exigências únicas de uma organização (Kanter, 1997). Nesse contexto, qualquer trabalho e/ou qualquer organização será sempre considerada como um "trampolim", conforme coloca Lópes Ruiz (2004).

Em uma lógica dominada pela visão de curto prazo, valores como confiança, lealdade e compromisso mútuo entre os funcionários não encontram espaço para serem construídos (Sennett, 1999). Essa é uma realidade na qual as relações profissionais não chegam a se aprofundar, como fica evidenciado no filme $O$ Corte a partir dos diálogos de Bruno com seus pares após a sua nova contratação.

Antes de sua demissão, Bruno se posicionava claramente na lógica de "old deal" conforme foi evidenciado no início do filme na festa em que o chefe lhe entrega um prêmio, elogindo a sua lealdade e as suas idéias criativas que tanto ajudaram a produtividade da empresa. Por fim, ilustrarmos a lógica de "old deal" de Bruno no quadro a seguir:

Quadro 4: A lógica de old deal de Bruno Davert

\begin{tabular}{|l|l|}
\hline Visão de & - Crença na empresa e no produto que vende. Laços emocionais, além dos ganhos financeiros. \\
Bruno sobre & - o trabalho é um meio de servir à sua família, vivendo uma vida sob controle e previsível (uma \\
o trabalho & carreira que se iniciava em uma empresa quase invariavelmente terminaria na mesma) \\
\hline $\begin{array}{l}\text { Como Bruno } \\
\text { se relaciona }\end{array}$ & - Companheiros de trabalho como amigos. \\
no trabalho & - Conversas sobre a vida pessoal. Participação destes em festas e ritos de integração; \\
\hline \hline
\end{tabular}




\begin{tabular}{|lr|l|}
$\begin{array}{l}\text { Bruno e } \\
\text { Ambiente no } \\
\text { trabalho }\end{array}$ & $\begin{array}{l}\text { - Sala com objetos pessoais (retratos, prêmios e recordações pessoais). } \\
\text { - Espaço é um prolongamento de sua casa, onde ele tem um sentido de pertencimento e } \\
\text { permanência. }\end{array}$ \\
\hline
\end{tabular}

Fonte: Os autores.

Portanto, depois do processo de fusão organizacional, Bruno Davert é obrigado a romper abruptamente com o modelo mental que não está mais alinhado à cultura da "nova" organização. Nesse sentido, sua permanência na empresa a partir da fusão somente seria viável se Bruno conseguisse internalizar "as regras do jogo" do "new deal".

\section{Dilemas Éticos e a Ética Corporativa com Base no Filme 0 Corte}

O filme apresenta várias questões que se tangenciam com dilemas éticos, fato que é muito comum nos dias atuais. As referências de certo e errado esbarram na necessidade de vencer e superar os desafios e as dificuldades. 0 personagem principal, obcecado pela ideia de eliminar seus concorrentes, luta internamente para encontrar justificativas para suas ações, há momentos em que se questiona em relação ao caminho a seguir, considera se deveria parar com os crimes ou se unir aos trabalhadores na mesma situação. Contudo, não faz uma coisa nem outra, e continua a procura de suas vítimas até obter o emprego desejado. Contrariando a lógica do personagem, provavelmente de forma proposital, o filme apresenta aos espectadores um dilema ético familiar: quando Bruno Davert vê o filho envolvido em problemas de ordem legal, reprova a atitude do jovem, por não considerá-la correta. Mas, adota uma atitude pragmática, novamente atropelando as fronteiras entre o certo e o errado, colaborando para eliminar as provas da culpabilidade do filho. Essa decisão revela mais uma vez o perfil utilitarista de Bruno Davert. Ocorre que, no filme, Davert toma uma decisão utilitarista de forma individualista visando encobrir um erro. Nesse caso, o utilitarismo é utilizado de forma negativa, conflitando com a ética, e beneficiando determinado grupo de pessoas: a família de Davert. No filme, a sequência 19, na qual Maxime Davert, filho de Bruno, comenta que teve que fazer um trabalho escolar sobre Nicolau Maquiavel, cujo tema era "o fim justifica os meios", iniciando-se uma discussão sobre o comportamento ético.

A mensagem final da obra deixa claro o "efeito dominó" da ética corporativa (reflexo de tempos difíceis de constante competitividade) na ética familiar e individual de Bruno. Além de sua própria sobrevivência, visava à manutenção de sua família. Até a manutenção do emprego de Bruno, havia certa harmonia entre a sua família e na relação dos membros com a sociedade, entretanto, com a nova configuração familiar a partir do desemprego, há uma completa reestruturação nas relações de cada membro com ao ambiente externo. Desta forma Bruno opta também por não mais cumprir o contrato psicológico "social", privando-se de qualquer tipo de punição nesta decisão de "toma lá, da cá". No filme esta ética individualista é reforçada não só por Bruno, mas também por seu filho Máxime, que se envolve em práticas de roubos, independente das consequências dos seus atos para a família e a sociedade.

Na sequência 20, quando Bruno Davert invade a casa de Raymomnd Machefer, mais uma vez temos as contradições éticas embasando as relações entre o discurso e a prática, que provocam e surpreendem o público até a sequência final, quando Bruno Davert já empregado e pensando em tudo que fez para conseguir a vaga, tem súbito susto, pois raciocinando segundo sua lógica de competitividade extremada, de utilitarismo e de individualismo, conclui ser agora um alvo a ser eliminado.

Uma característica singular deste filme é o incrível cuidado com que o Diretor coloca, aqui e ali, referências, por vezes bastante sutis, àquilo que se passa no contexto psicológico e social 


\section{A ética corporativa e o cenário competitivo: uma análise dos dilemas éticos nas relações de trabalho contemporâneas a partir do filme "0 Corte" (Le Couperet)}

dos personagens, tangenciando o dilema do consumismo da sociedade capitalista. Os sinais de decadência financeira da família Davert devido ao desemprego de Bruno - a perda da TV por assinatura, a falta de mantimentos básicos, etc. - se encontram presentes no diálogo dos personagens - sempre com um toque de mudo desespero. Outro exemplo, mais sutil, é que, ao longo de todo o filme, o personagem principal se vê como que "perseguido" por imagens publicitárias onde são retratados diversos itens de consumo de luxo. Estas surgem em momentos-chave da trama e servem para atormentar ainda mais o protagonista, lembrandoo, a todo o momento, do mundo - o mundo corporativo com suas estratégias de Marketing do qual ele já fez parte e para o qual anseia tão desesperadamente retornar.

$O$ Corte pode ser observado como uma importante crítica social, pois mostra os efeitos gerados pela competitividade predatória dos novos arranjos organizacionais imposto pela globalização de mercados. A produção revela essa conclusão, pois mostra que o herói não é o jovem e ambicioso executivo tão valorizado pela sociedade, mas sim o profissional que consegue "driblar" a voracidade e a lógica das relações de trabalho das empresas contemporâneas. 0 filme retrata seu protagonista, Bruno Davert, como disfuncional, egoísta, utilitarista individualita. Essas características foram reunidas, de acordo com as abordagens dos princípios filosóficos da ética (Carroll, 1996; Ferrell, Fraedrich e Ferrell, 2001) no quadro apresentado a seguir:

Quadro 5: Princípios Filosóficos da Ética versus Características de Bruno Davert no filme “O Corte"

\begin{tabular}{|c|c|c|}
\hline Abordagens & Princípios & Descrição \\
\hline $\begin{array}{l}\text { Abordagem } \\
\text { Teleológica }\end{array}$ & Egoísmo & $\begin{array}{l}\text { "Bruno Davert: Tornei-me hostil e anti-social." Concentra-se no objetivo } \\
\text { final: obter emprego do seu nível salarial e intelectual - é o único } \\
\text { interesse que possui no momento. Toma decisões e não considera as } \\
\text { pessoas que seriam afetadas com as suas ações. }\end{array}$ \\
\hline $\begin{array}{l}\text { Abordagem } \\
\text { Teleológica }\end{array}$ & Utilitarismo & $\begin{array}{l}\text { "Bruno Davert: Sempre fui um marido, um pai, um leal funcionário." } \\
\text { Acredita que suas atitudes beneficiam sua família, já que com isso } \\
\text { voltaria a fornecer a mesma qualidade de vida que possuíam antes do } \\
\text { desemprego. }\end{array}$ \\
\hline $\begin{array}{l}\text { Abordagem } \\
\text { Deontológica }\end{array}$ & $\begin{array}{c}\text { Princípio dos } \\
\text { Direitos }\end{array}$ & $\begin{array}{l}\text { "Chefe: Por seus } 15 \text { anos de lealdade a empresa que também é sua, por } \\
\text { favor, aceite este singelo presente para registrar a qualquer momento } \\
\text { suas idéias criativas que tanto ajudaram nossa produtividade." No início } \\
\text { do filme crê que a empresa possui respeito por seus colaboradores e } \\
\text { que os reconhecem. As ações da empresa deveriam de fato maximizar a } \\
\text { utilidade para as várias partes envolvidas no processo produtivo e não } \\
\text { apenas para quem decide. }\end{array}$ \\
\hline $\begin{array}{l}\text { Abordagem } \\
\text { Deontológica }\end{array}$ & $\begin{array}{l}\text { Princípio da } \\
\text { Justiça }\end{array}$ & $\begin{array}{l}\text { "Bruno Davert: Deveríamos nos unir, não brigar por ninharia. Enquanto } \\
\text { os diretores riem ou pior, nem sequer vêem que existimos." Possui } \\
\text { consciência que a ação dos diretores não fornece direitos iguais a } \\
\text { todos, e tem a consciência de que a união é uma forma possível de } \\
\text { alcançar seus direitos. }\end{array}$ \\
\hline
\end{tabular}

Fonte: Os autores baseados na abordagem dos Princípios Filosóficos da Ética (Carroll, 1996; Ferrell, Fraedrich e Ferrell, 2001).

Os dilemas éticos identificados ao longo do filme enfatizam a importância da compreensão da ética corporativa, dos valores e crenças que embasam a cultura, e do alinhamento do discurso organizacional com a prática para a longevidade e o desenvolvimento sustentável. Somente com esta clareza e por meio da transparência, será possível evitar que indivíduos deturpem 
Fábio Francisco de Araujo e Patricia Amélia Tomei

mensagens como "competir e vencer", com comportamentos egoístas e utilitaristas. 


\title{
Considerações Finais
}

Realizou-se ao longo deste artigo uma discussão temporal sobre a globalização e algumas consequências desse movimento a partir da competitividade excessiva no contexto organizacional. A nova realidade do mundo contemporâneo, cada vez mais efêmera, instável e flexível (Harvey, 1992), produz grandes mudanças no ambiente organizacional, sobretudo para acompanhar a alta competitividade que se impõe às empresas e aos trabalhadores.

A competição agressiva entre as empresas e, também, entre os indivíduos, abordadas metaforicamente em " $O$ Corte", está se tornando uma realidade cada vez mais comum, sobretudo depois da eliminação virtual das fronteiras locais (Lévy, 1997; Santos, 1996), que oferece maior facilidade de acesso aos competidores. Embora existam inegáveis benefícios trazidos pela globalização dos mercados (Levitt, 1990; Kotabe e Helsen, 2000), é preciso uma atenção especial para gerenciar no que for possível os seus malefícios, tais como patologias psicossociais perigosas para as relações humanas (Canclini, 2003; Vakaloulis, 2001).

Neste sentido, neste artigo retomamos as questões colocadas por Azize (2009) que tangenciam as reflexões sobre o capitalismo de Comte-Sponville (2005):

\begin{abstract}
"A crítica ao capitalismo e aos formatos de organização do trabalho elegeu mais um inimigo no início do século XXI, e, mais uma vez, este inimigo aparece representado também em produções cinematográficas. Este inimigo está encarnado em idéias como reengenharia, reestruturação produtiva, fusões, cortes, acumulação flexível, globalização, terceirização, flexibilização, adaptação e nas consequências humanas desses processos. $O$ inimigo são as falsas promessas de liberdade, criatividade, autonomia e reinvenção de si que o novo modelo flexível de trabalho prometia; as novas vítimas não são somente os operários das linhas de montagem (que não deixaram de existir, tampouco deixaram de ser as principais vítimas quando mudanças bruscas transformam o modelo de produção e acumulação), mas também os membros das classes executivas e administrativas, que se vêem cedo envelhecidos e obsoletos por um sistema que pede constante inovação tecnológica e reinvenção de competências."
\end{abstract}

Como o sistema capitalista pode absorver as críticas que esses filmes encarnam aos valores da flexibilidade, da liberdade, da autonomia, valores estes que sustentam o discurso do sistema hoje? Se olharmos para outras crises do capitalismo, e para a sua capacidade de re-invenção e absorção da crítica, não se duvida que adaptações nos argumentos que levam os quadros a engajar-se no sistema de acumulação levem a novos "espíritos do capitalismo". (Azize, 2009, p.81 e 91).

A reflexão da ética corporativa e do posicionamento dos indivíduos diante dos dilemas éticos pode ser uma forma de enfrentar o comportamento excessivamente competitivo imposto pela lógica do "new deal". Além disso, é preciso reconhecer os seus efeitos indesejáveis, criando mecanismos que ressaltem a necessidade da transparência e da governança corporativa para a convivência ética entre os membros de uma organização.

Os estudos de ética no ambiente organizacional (Carroll, 1996; Guy, 1990; Harrington, 1991; Mathews, 1987) ofereceram uma rica contribuição para lidar com a problemática apresentada pelo filme. A ética corporativa poderia ser um instrumento útil aos membros da organização, visando reeducar os indivíduos para fazer com que os efeitos de um ambiente de alta competitividade sejam mitigados e, assim, buscar o equilíbrio entre a cooperação e a assertividade, respeitando os limites sociais e morais (Treviño, 2000).

O filme "O Corte", digno de um "conto de fadas corporativo neoliberal", ironiza a mensagem do herói ambicioso tão valorizado pela sociedade contemporânea. Uma questão para reflexão estaria nos impactos gerados pelo descasamento, de um lado, entre as práticas e o cotidiano 
dos trabalhadores nas empresas (cada vez mais assoberbados pelas demandas do trabalho) e, do outro, as representações sugeridas por filmes como " $O$ Corte", no qual encontramos a nostalgia de uma vida embasada em valores como lealdade, confiança, e equilíbrio entre o trabalho e a vida familiar. No plano individual, esse descasamento talvez termine por gerar ainda mais angústias para os trabalhadores, que como "malabaristas chineses" precisam correr de um lado para o outro para não deixar os "pratos" da vida familiar e profissional desabar aos seus pés.

Deixando de ser o mediador da realização do ego no campo social, o trabalho talvez se torne apenas um meio de ganhar a vida. As empresas, então, estariam sendo reduzidas a meras provedoras de salários. Tendo em vista o fato de que ainda são muitos recentes, os impactos gerados por essas mudanças ainda parecem longe de serem compreendidos. Colling e Porras (1995) realizaram uma pesquisa sobre organizações com longas histórias de sucesso e perceberam que nessas empresas a maximização do retorno aos acionistas não estava entre as forças dominantes das suas visões. A conclusão dos autores é que "negócios são mais do que atividade econômica, mais do que apenas fazer dinheiro".

A escolha desse caminho nos remete imediamente a questionamentos em termos de efetividade de resposta aos dilemas da chamada "pós-modernidade flexível" (Harvey, 1992). Qual seria um programa ético adequado para enfrentar as questões atuais? De que forma pode ser implementado o processo de internalização da ética nas organizações frente a um mercado sem fronteiras? Quais os instrumentos mais adequados de gestão ética para lidar com o excesso de competitividade na sociedade contemporânea? São alguns questionamentos que merecem maior atenção e pesquisas futuras.

\section{Referências}

ARAUJO, F.F. Expectativas para o Desenvolvimento e a Formação do Administrador no Mercado Globalizado: Um estudo de caso em uma universidade brasileira. Revista Facef Pesquisa, vol. 14, no. 2, 2011, p. 207-224.

ARAUJO, F.F., CHAUVEL, M.A. Marketing de Cinema Francês no Brasil: um Estudo Exploratório. In: XXXII EnANPAD - ENCONTRO NACIONAL DA ASSOCIAÇÃO NACIONAL DE PÓSGRADUAÇÃO EM ADMINISTRAÇÃO. Anais... Rio de Janeiro, 2008.

ARRIGHI, G. O Longo Século XX: dinheiro, poder e as origens de nosso tempo. Rio de Janeiro: Contraponto, 1996.

AZIZE, R.L. Desemprego executivo: a crítica ao terceiro espírito do capitalismo no cinema contemporâneo. Revista Brasileira de Ciências Sociais, vol.24, n.69. São Paulo, 2009.

BAUDRY, J.L. Ideological effects of the basic cinematographic apparatus. Film Quarterly, vol.28, n‥ 2, 1974.

CANCLINI, N.G. A Globalização Imaginada. São Paulo : Editora Iluminuras, 2003.

CAPPELLI, P. The new deal at work. Boston: Harvard Business School Press, 1999.

CARROLL, A.B. Business e Society: Ethics and Stakeholders Management. 3a․ed. Cincinnati, ITP, 1996.

CEA,G.S., ZEN, R.T. Elementos Sociais do Mundo do Trabalho na Ficção Cinematográfica: provocações de "O Corte" publicado na coletânea. In: A.F. Fiúza e G. H. da Conceição (org), Política, Educação e Cultura. Coleção Sociedade, Estado e Educação, EDUNIOESTE, 2008.

COLlinS, J.C., PORRAS, J.I. Feitas Para Durar: Práticas bem-sucedidas de empresas visionárias. 
Rio de Janeiro, Rocco, 1995.

CRESSEY, D.R., MOORE, C.A. Managerial Values and Corporate Codes of Ethics. California Management Review, vol.25, no.4, 1983, p. 53-77.

COMTE-SPONVILLE, A. O capitalismo é moral? Tradução de Eduardo Brandão. Rio de Janeiro: Ed. Martins Fontes, 2005.

COSTA-GAVRAS, C. O Corte (Título Original Le Couperet). Longa-metragem. Produção: França / Bélgica / Espanha, 2005.

DAIGNEAULT, M. G., GUTHRIE, J., NAVRAN, F. Managing Ethics Upwards. Ethics Resourc Center, documento de trabalho. Washington. 2001. Disponível em: <http://www.ethics.org>. Acesso em: 25.mar. 2010.

DALTON, D., METZGER, M. B., HILL, J.W. e SIMMERS, W.W. The 'New' U.S. Sentencing Commission Guidelines: A Wake-up Call. Academy of Management Executive, vol.8, no.1, 1994.

DANJOU, I. L' entrepreneuriat: un champ fertile à la recherche de son unité. Revue Française de Gestion, v. 28, n. 138, p.109-125, 2002.

DONALDSON, T. e PRESTON, L.E. The Stakeholders Theory of Corporation: Concepts, Evidence and Implications. Academy of Management Review, vol.20, no. 1, 1995, p.65-91.

FERRELL, O.C., FRAEDRICH, J., FERRELL, L. Ética Empresarial: Dilemas, Tomadas de Decisões e Casos. 4ª ed., Rio de Janeiro: Reichmann \& Affonso Editora, 2001.

FORRESTER, V. O horror econômico. São Paulo: Editora da Universidade Estadual Paulista,UNESP, 1997.

FORRESTER, V. Uma estranha ditadura. São Paulo: Editora da Universidade Estadual Paulista, UNESP, 2001.

FREEMAN, E. Strategic Management: A Stakeholder Approach. Boston: Pitman, 1984.

GEERTZ, C.A. Interpretação das Culturas. Rio de Janeiro: Zahar, 1973.

GREENBERG, D.N. Disentangling cultures: Similarity, interaction, and cultural agreement in the multinational organization. Boston: Boston College, 1999.

GUY, M.E. Ethical Decision Making In Everyday Work Situations. New York: Quorum Books, 1990.

HAMEL, G. e PRAHALAD, C.K. Do you really have a global strategy? In: K. Ohmae, The Evolving Global Economy. Harvard Business Review Book. Jul-Ago, 1985.

HARRINGTON, S.J. What Corporate America is Teaching about Ethics. Academy of Management Executive, vol. 5, ํㅜ 1, 1991, p.21-30.

HARVEY, D. Condição pós-moderna. São Paulo: Edições Loyola, 1992.

HIRSCHMAN, E., STERN, B.B. Women as Commodities: Prostitution as Depicted in the Blue Angel, Pretty Baby and Pretty Woman. Advances in Consumer Research, v. 21, 1984.

HOLBROOK, M.B. Popular Appeal versus Expert Judgments of Motion Pictures. Journal of Consumer Research, vol. 26, nํ.. 1, 1999, p.144-155.

JONES, T.M. Instrumental Stakeholder Theory: A Synthesis of Ethics and Economics. Academy of Management Review, vol.20, n‥ 1, 1995, p.404-437.

KANTER, R.M. Quando os gigantes aprendem a dançar: dominando os desafios de estratégias, 
gestão e carreiras nos anos 90. Rio de Janeiro: Campus, 1997.

KOTABE, M. e HELSEN, K. Administração de Marketing Global. São Paulo: Atlas, 2000.

KOTLER, P. Global Standardization: Courting Danger. The Journal of Consumer Marketing, vol. 3, vol. 2, 1986.

LEVITT, T. A. Imaginação de Marketing. Tradução de Auriphebo Berrance Simões. 2a ed. São Paulo: Atlas, 1990.

LÉVY, P. L'intelligence collective: pour une anthropologie du cyberspace. Paris: Libraire Les Éditions La Découverte, 1997.

LOIZOS, Peter. Vídeo, filme e fotografias como documentos de pesquisa. BAUER, M.W.; GASKELL, G. (Org). Pesquisa qualitativa com texto, imagem e som: um manual prático. 2ª . Ed. Petrópolis: Vozes, 2008, p. 137-155.

LÓPES RUIZ, O.J. O "ethos" dos executivos das transnacionais e o espírito do capitalismo. Campinas, SP. Tese de Doutorado em Ciências Sociais, Instituto de Filosofia e Ciências Humanas, Universidade Estadual de Campinas, 2004.

MATHEWS, M.C. Codes of Ethics: Organizational Behavior and Misbehavior. In: W. C. FREDERICK (ed.), Research in Corporate Social Performance and Policy: Empirical Studies of Business Ethics and Values, v. 9. Greenwich, Jai Press, 1987, p. 107-130.

METZGER, M.B., DALTON, Dan; H. e HILL, J.W. The Organization of Ethics and the Ethics of Organizations: The Case for Expanded Organizational Ethics Audits. Business Ethics Quarterly, vol.3, no. 1, 1993, p.27-43.

MOTT, D.K.D. de. Ethics. Gale Encyclopedia of Psychology. 2ª ed. Gale Group, 2001.

NADLER, D.A., e LAWLER, E.E. Quality of work life: perspectives and directions. Organizational Dynamics, vol.11, n‥ 3, 1983, p.20-30.

PASSARELLI, C. A. Imagens em diálogo: filmes que marcaram nossas vidas. In: SPINK, M. J. (Org.). Práticas discursivas e produção de sentidos no cotidiano. São Paulo: Cortez, 2004.

RANSOME, P. Sociology and the Future of Work: Contemporary Discourses and Debates. Aldersho: Ashgate, 1999.

RIFKIN, J.G.P. The End of Work: The Decline of the Global Labor Force and the Dawn of the PostMarket Era. New York: Putnam's Sons, 1995.

ROSE, D. Análise de imagens em movimento. In: BAUER, M. W.; GASKELL, G. (Orgs.). Pesquisa qualitativa com texto, imagem e som. 2ª . Ed. Petrópolis: Vozes, 2008, p. 342-364.

ROUSSEAU, D.M. Psychological contract in organizations. Thousand Oaks: Sage, 1995.

SANTOS, M. A natureza do espaço: Técnica e Tempo. Razão e Emoção. São Paulo: Hucitec, 1996.

SENNETT, R. A corrosão do caráter. Rio de Janeiro: Record, 1999

SETHI, P. Codes of Conduct for Multinational Corporations: An Idea Whose Time Has Come. Business and Society Review, vol.104, v.3, 1999, p. 225-242.

SIMON, H.A. Administrative Behavior. Cambridge: Univ Press, 1976.

SHIMP, T. Propaganda e Promoção: Aspectos complementares da comunicação integrada de marketing. 5a. ed. Porto Alegre: Bookman, 2002.

SROUR, R.H. Ética Empresarial: Posturas Responsáveis nos Negócios, na Política e nas Relações 
Pessoais. Rio de Janeiro: Ed. Campus, 2000.

SUAREZ, M.C. ; TOMEI, P. A. Longe de um Final Feliz ? Uma análise das novas relações de Trabalho a partir do filme Em Boa Companhia. Revista Symposium, v. 5, 2007, p. 6-15.

TOMEI, P.A., HILAL, A. Seductive Leadership \& Culture of the Ephemeral: Case Study The Devil Wears Prada. In: GLOBAL BUSINESS AND TECHNOLOGY ASSOCIATION - GBATA. International Conference. Anais... Moscou, 2006.

TREVIÑO, L.K., HARTMAN, L.P., BROWN, M. Moral Person and Moral Manager: How Executives Develop a Reputation for Ethical Leadership. California Management Review, vol.42, no.4, 2000, p.128-142.

TURNER, G. Cinema Como Prática Social. São Paulo: Summus, 1997.

VAKALOULIS, M. Le Capitalisme post-moderne. Élements pour une critique sociologique. Paris: Presses Universitaires de France, 2001.

VICTOR, B., CULLEN, J.B. The Organizational Bases of Ethical Work Climates. Administrative Science Quarterly, vol.33, nํ.1, 1988, p.101-125.

VOGL, F. Ethics e Compliance in a Global Economy. Ethics Resource Center, documento de trabalho. Washington. 2000. Disponível em: <http://www.ethics.org>. Acesso em: 25.mar. 2010.

WILLIAMSON, O.E. Transaction-cost economics: the governance of contractual relations. Journal of Law and Economics, vol. 22, no..1, 1979, p.233-262. 